\title{
髄内釘横螺子固定法の適応と問題点について
}

\begin{tabular}{|c|c|c|c|c|c|}
\hline 松 & 本 & 直 & 之 · 加 & 䇝 & 洋 \\
\hline 野 & 村 & 笺 & 治・森 & 田 & 秀 \\
\hline 帖 & 佐 & 博 & 文・上 & 田 & 惠 \\
\hline 井 & 原 & 秀 & 俊 - 津 & 村 & \\
\hline
\end{tabular}

\section{Indication and Problems of Intramedullary Nailing with Screw Fixation}

by

\author{
N. Matsumoto, Y. Kamo, S. Nomura, H. Morita,
} H. Chosa, Y. Ueda, H. Ihara and H. Tsumura

Kyushu Rosai Hospital Orthopaedic Surgery

\begin{abstract}
During the years 1973 and 1982, we treated 92 cases of tibial or femoral fractures by using the Kuntscher medullary nails, which were supplemented by screw fixatisus.

The urpose this procedure is to avoid the rotational dislocation of the distal fragment of the fracture without loss of the advantages of the intramedullary nailing. Moreover, this procedure extended the indications for use of medullary nails. We reported the indication and the problems of this procedure.
\end{abstract}

はじめに

Küntscher 釘内釘を用いた骨接合術が，長管骨骨， 幹部骨折に対する優れた固定法であるととは，長い臨 床経験から広く認められている11233)(6)。しかしその 欠点として回旋固定力の不足, 骨䯣腔拡大部での固定 力の減弱が指摘されている。これらの欠点を補うべく 従来多くの工夫がなされてきた2)314. 当科では昭和 48 年以来，回旋防止を主目的とし Küntscher 髅内釗飞 横螺子固定を併用してきた．今回，本法を施行した症 例について検討を加え，その適応之問題点について述 ベる.

\section{対象}

1973 年 1982 年の 10 年間 $に ， K u ̈ n t s h e r$ 䯣内釘 を単独に使用した骨接合術は，274 骨折で，横螺子固 定を施行したあのは，92骨折である，その内訳は，大 腿骨 26 , 脛骨 66 骨折であり，偵関節に対しては 22 骨 折に施行されている．原則として本法では偽関節に対 し骨移植を行っていない.
横螺子は，大腿骨または脛骨の中下 3 分の 1 部の骨 折の場合は，通常その未梢側に 2 本の横螺子を用い， また偽関節や骨幹部粉哗骨折の場合は，2本〜 4 本の 横螺子を使用している.

$$
\text { 結果 }
$$

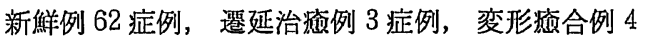
症例の全症例飞骨痖合をみ，偽関節 22 症例に骨移植 を行うとと無く骨痹合が得られた（図 1 )。偽関節位 で骨瘁合が得られなかった 1 症例は, 術後 1 年半にて 髄内釘の折損をきたしたものである（図 2）。本症例 は，偽関節部の末梢㑡に横螺子が 1 本しか使用されて いなかったために充分な固定性が得られなかったてと によると考えられた，てのため再手術は，中枢側に短 い Küntscher 釘をかみ合わせて double Küntscher 釘として打ち込み，更飞横螺子中枢側 2 本，末梢 側 2 本と骨移植を追加した.

合併症としては，前述した，Küntscher 釷の折損 1 症例, 螺子の折損 2 症例 (図 3 ), 内反变形 1 症例

(図 4)，骨髅炎の再発 2 症例である。乙のうち螺子 


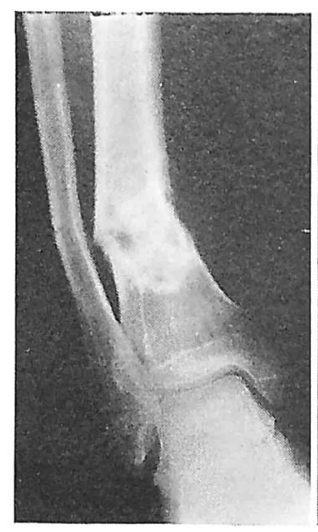

a. 術前

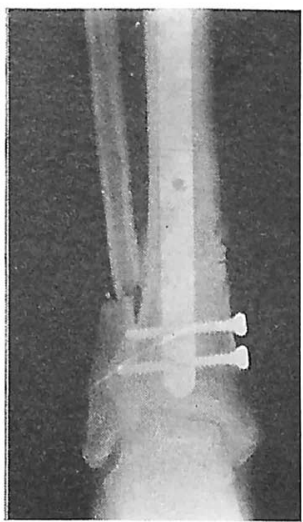

b. 術後

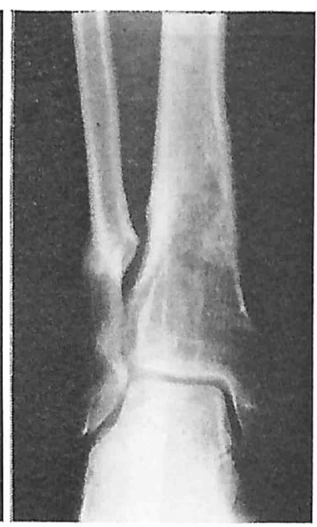

C. 術後 1 年

図 1 偽関節例，骨移植は行つていない

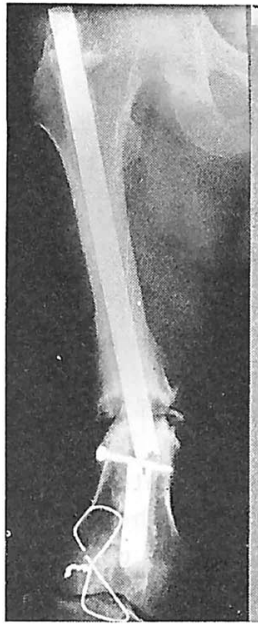

a . 県前

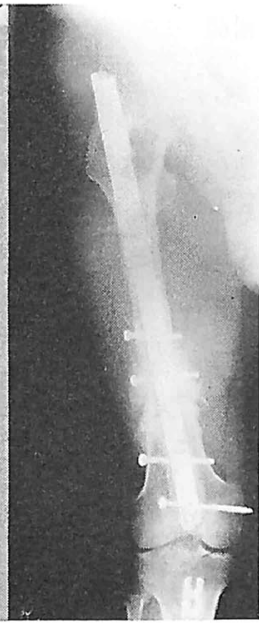

b. 術後

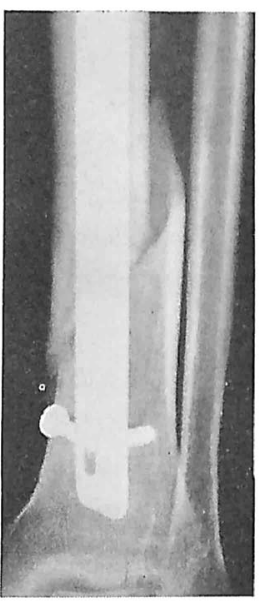

図 3 纙子折損例

図 2 喵内剑折損例 (a) 再手術は double Kühtscher 法を作用 (b)

折損例は，2例とも折損にかかわらず骨漓合を得た。 内反变形をきたした症例は，手術時の整復が不充分で あったことが考えられ反省点として挙げられる，骨髅 炎の再発を起こした 2 症例は，骨癁合を得た後，抜 釷，掻爬，淎流を行い骨䯣炎の治演をみた。

$$
\text { 考察 }
$$

Küntscher 釗の適応を拡大する為の方法として， Kaessman 法, bolt つき特殊 clover 釗 ${ }^{8)}$, double Küntscher 法，横螺子固定法などがあるがその中で む横螺子固定法は特殊な器具を要さず手技も容易であ る。
本法の 問題点としては，蝒子の 折損，Küntscher 釗の折損，放射線被爆星の增加等が举げられる。2 机 の横螺子で固定すること在則としているのは，それ により骨片の強固な固定が得られ，また螺子の折損の 可能性を減少させることを意図している。趾内剑に穿 つ穴を長円形にしているのは，鈳と骨との間の長軸方 向の sliding を残し, 冎折部の压迫を妨げないとと と，直接横螺子に負荷がかかるのを避け，その折損を 予防する為である. この他，長軸方向の圧迫を㕫げな い為には，原則として骨折部をはさみ近位と莩位両侧 同時に横螺子固定老行わない力がよい.しかし紛确骨 折でやむを得ず短縮子防を目的としててれを施行した 


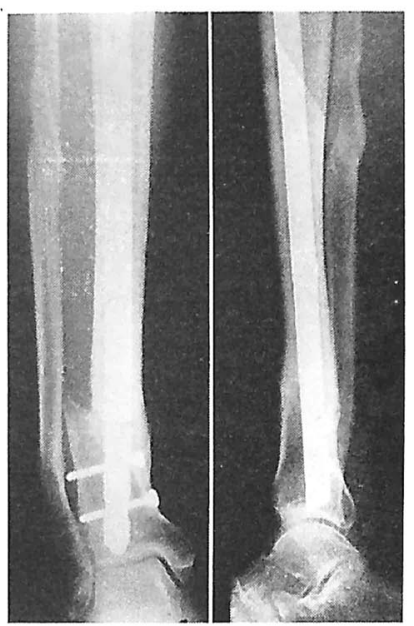

図4 内度缩形例

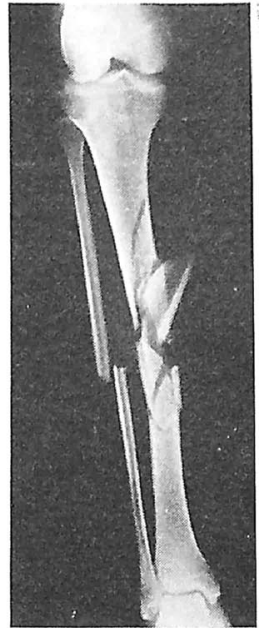

a. 術㸉

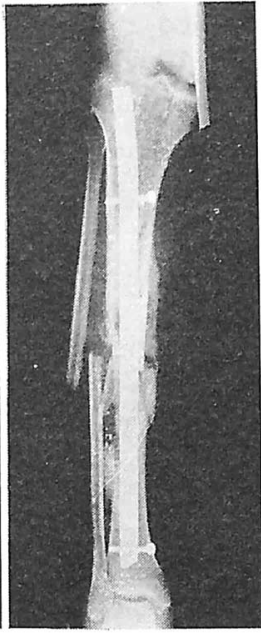

b. 術後

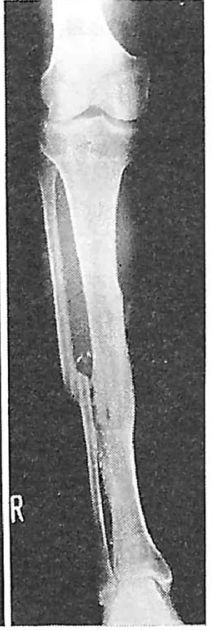

C. 術後 1 年

図 5 粉䂗骨折例

症例にて屯良好な骨痹合を得ている（図 5 ).

Küntscher 釷の折損の予防について言及すれば, 可能な限り太いKüntscher 釗を使用することと，釗 に穿つ穴を可能な限り骨折部より遠位に置くことであ る.

もう一つの重要な問題点である放射線被爆量の増加 は本法に於てはある程度やむを得ないことである。乙 の事実を充分に認識し，操作を適確に，且つ迅速に行 うととを心脚けることが重要である。つまり手技に習 熟することにより最小限度にくい止めることが可能と なる。

本法の適応としては，(1)大腿骨及び脛骨の中止 3 分 の 1 , 中下 3 分の 1 部骨折, (2)大腿骨, 硦骨の偽関節 （特に不適切な Küntsher 釷の使用による偽関節）， (3)大腿骨, 脛骨の骨幹部粉哗骨接，(4)皮原の癜痕が強 く骨移植や plate 固定がためらわれる症例等である。 特にKüntscher 釗による偽関節の昜合は, 骨幹部の 具折でありながら骨䯣腔が拡大しており，本邦で使用 されている $15 \mathrm{~mm}$ までの Küntscher 釗では充分な 固定を得られないことああり本法の適応となる。また 骨幹部の粉砕骨折の場合には，骨片が旅痕組織により ある程度動かなくなるまで約 1〜2力月間の鍋線辛引 を行った後本法を施行し良好な結果を得ている.

\section{結語}

Küntscher 噵内釗の横螺子による固定は，他の方
法にみられないKüntscher 釘の長所を生かし，また その適応簌团を拡大する非常に有用な骨接合法である と若えられる.

文献

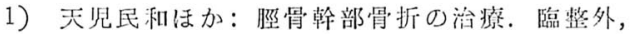
2: 443-451, 1967.

2) Böhler, J.: Closed intramedullary nailing of the femur. Clin. Orthop. 60: 51-67, 1968.

3) Brav C. E. A.: The use of intramedullary nailing for nonunion of the femur. Clin Orthop. 60: 69-75, 1968.

4) Funk F. J., Jr. et al.: Supplementary fixation of femaral fractures. Clin. Orthop. $60: 41-48,1968$

5)㸚原一輝ほか：閉鎖性䯣内猃。整形外科，18: 1189-1197, 1967.

6) 柏木大治 ほか：大腿骨督体部骨折の手術的痖 法. 阽整外, 2: 1133-1137, 1967.

7) Küntscher, G. : Praxis der Marknagelung. 天児訳, 蹎内釷の実際, 1962.

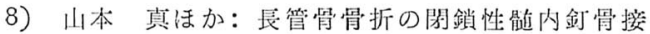
合術の新展開(螺子横固定と噵闪圧迫固定法) 飞 ついて. 臨整外, 8: 466-479, 1973.

質 問 佐賀医科大学 忽那 龍雄 䯣内釬横螺子固定法を用いて髄内釷の適応を拡大 し，骨幹端部を固定できたとしても，プレート固定に まさる固定力が得られるのでしょうか？ 


解 答 九州学災病院 松本 直之

Plate 固定より強固である.それは Küntscher 釘 による海綿骨の固定に螺子の固定が加わるからであ る.

質 問産業医科大学 伊地知正光 横螺子を使えば，外固定は全例に不要になるのか.

解 答詶学災病院 松本 直之 横螺子を 1 本でなく 2 本使用するのは，1本では特 に骨髄腔の広い部位では螺子を中心とする回転が起と
り得て固定力は不充分であると考えられる．2本目の 螺子はそれを防止すると考える.

横螺子 2 本使用すれば外固定の必要は和い.

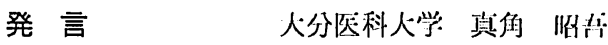

(1) 私どもが開発した手術法の演者の意見に筫成す る.

(2) ただ本法で注意すべきととは；㸡射線被䈋が多 くなることで，なるだけイメージ俌用㺫間を短くする ようにするとと. 